\title{
Book review: From the Pleistocene to the Holocene
}

\author{
John E. Dockall \\ Prewitt and Associates, Inc. 2104 Donley Drive, Suite 400, Austin, Texas, USA. Email: Jdockall@paiarch.com
}

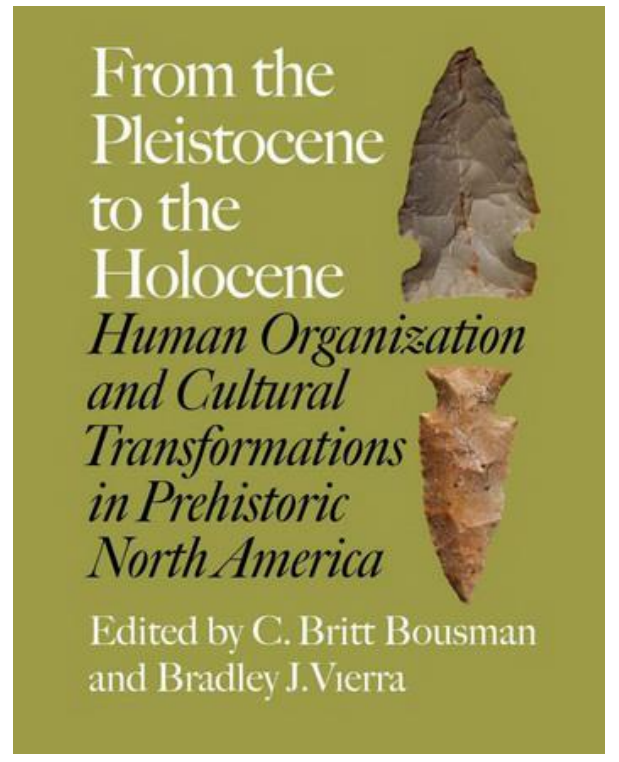

From the Pleistocene to the Holocene: Human Organization and Cultural Transformations in Prehistoric North America

edited by C. Britt Bousman and Bradley J. Vierra

Texas A\&M University Press, 2012, pp. 327. ISBN 978-1-60344-760-7

http://www.tamupress.com/product/From-the-Pleistocene-to-the-Holocene,7150.aspx

From the Pleistocene to the Holocene, edited by Bousman and Vierra, resets our thinking on the pace and overall patterns of transitions in North America at this time. This book brings together detailed archaeological syntheses from multiple geographic regions. The result is a volume that stands alone as a new interpretative framework for cultural change during the transition from the last Ice Age to the beginning of the Holocene.

The text is organized into 12 chapters with Chapter 1 as an introduction to the volume by Bousman and Vierra. This chapter establishes the chronological and climatological framework for the subsequent region-specific portions. The editors note three themes to the book and each chapter: (1) revision of regional archaeological sequences and chronologies, (2) taphonomic and preservation factors, and (3) the use of paleoenvironmental data to

Published by the School of History, Classics and Archaeology, University of Edinburgh ISSN: 2055-0472. URL: http://journals.ed.ac.uk/lithicstudies/

This work is licensed under a Creative Commons Attribution 2.5 UK: Scotland License. 
evaluate changes that occurred. The succeeding chapters are arranged to present geographic coverage from west to east across North America (inclusive of Alaska). A portion of each chapter also assesses the apparent technological changes across the Pleistocene/Holocene transition. These changes are evaluated with reference to climatic, faunal, and other subsistence data for each region. In Chapter 2, Michael Bever discusses the technological variability among several microblade technologies as part of an adaptive response to environmental and climatic change in post-glacial Alaska at the Pleistocene-Holocene transition. Bever discusses the strong technological and typological similarities to similar assemblages in Northeast Asia. Chapter 3, by Chatters and others, present biological and archaeological evidence from the Pacific Northwest which suggests a region-wide ethnic replacement event of Paleoindian groups (Western Stemmed Tradition and Old Cordilleran Tradition) by maritime-adapted coastal groups. In Chapter 4, Rosenthal and Fitzgerald argue that the traditional concept of Pleistocene big game hunting did not exist in western California. Data from the earliest-dated occupations show reliance upon diverse resources into the Holocene period. For Chapter 5, Jones and Beck portray changes in technology and subsistence practices in the Great Basin from the Paleoarchaic to Desert Archaic as a response to decreased wetlands. In Chapter 6, Sanchez and Carpenter, present data to argue the Paleoindian to Archaic transition resembles that of the American Southwest. Chapter 7, by Larson, presents evidence that changes in settlement, technology, and subsistence were more pronounced between early and later Paleoindian groups than between Paleoindian and early Archaic groups in the Northwestern Plains and Central Rocky Mountains regions. For Chapter 8, Vierra and colleagues examine lithic assemblage and raw material variability for three regions along the northern part of the Rio Grande River in New Mexico. They note both raw material and point style changes that favor maintainability and durability for the Early Archaic that correlates with concomitant changes in subsistence and resource availability. In Chapter 9 Bousman and Oksanen provide a much needed review and reassessment of the Late Paleoindian to Early Archaic transition in Texas and note that for ca. 2600 years groups (Firstview) on the Southern High Plains continued a Paleoindian lifeway while other groups (Golondrina) had adopted patterns more akin to Archaic groups. Because of this mix of lifeways, the authors suggest that the term Proto-Archaic be used following Alex Krieger in 1964. In Chapter 10, Kay uses Paleoarchaic to denote the transitional period of time between Paleoindian and Archaic lifeways for the Ozark region noting cultural and technological changes that were more likely responses to local rather than regional environmental changes. For Chapter 11 Driskell and colleagues identify a very nuanced transition between Paleoindian and Early Archaic periods in the Middle Tennessee Valley and Highland Rim. They cite a generalized forager subsistence pattern spanning the transition even while significant changes in lithic technology were taking place. In Chapter 12, Carr and Adovasio discuss the difficulty of identifying a clear transition between Paleoindian and Early Archaic for the northeastern United States since much of the existing Pleistocene-Holocene information indicates an existing generalized subsistence and foraging lifeway.

This book is a welcome review of a crucial time across North America. Salient benefits are the environmental, climatic, archaeological, chronological and subsistence data that are directed at each synthesis. Sections on Northeastern Mexico, the Southeast, and a concluding chapter would have been welcome. These are minor criticisms and do not detract from the contribution that this volume makes to understanding changes across the PleistoceneHolocene transition for North America. This book is a necessary resource for researchers concerned with Paleoindian or Archaic groups but also should be digested by most prehistoric archaeologists in North America and Mexico. 